\title{
A rare case of turner syndrome mosaicism in an African black woman
}

\author{
Yordanka Piña Rivera, Godfrey Mutashambara Rwegerera* \\ Department of Medicine, Princess Marina Hospital; Department of Internal Medicine, University of Botswana, Gaborone, \\ Botswana
}

Received: July 30, 2016

DOI: $10.5430 /$ crim.v3n4p44
Accepted: September 17, $2016 \quad$ Online Published: September 19, 2016

URL: http://dx.doi.org/10.5430/crim.v3n4p44

\begin{abstract}
Turner syndrome (TS) is a chromosomal disorder caused by partial or complete absence of an X chromosome in at least one tissue of the body with about $50 \%$ of patients having a different chromosome formula. The $45, \mathrm{X} / 46, \mathrm{XY}$ mosaicism variety is rare. We present a case of a 32-year-old black African female patient with a history of primary amenorrhea and clinical stigmata of TS without signs of virilization. The laboratory parameters were consistent with the characteristic hypergonadotropic hypogonadism found in Turner Syndrome. Laparoscopy showed streak gonads and hypoplastic uterus and the findings of the cytogenetic studies were consistent with a diagnosis of 45, X/46, XY Mosaicism. The chromosome study was decisive to confirm the diagnosis.
\end{abstract}

Key Words: Turner syndrome, 45, X/46, XY mosaicism, Botswana

\section{INTRODUCTION}

Turner syndrome is a chromosomal disorder characterized by the presence of a variable number of changes in the phenotype and internal organs, with the gonadal dysgenesis and short stature the typical findings. The syndrome is caused by partial or complete absence of an X chromosome in at least one tissue of the body. ${ }^{[1]}$ It was described in 1938 by Henry $\mathrm{H}$. Turner in seven women with a condition characterized by short stature, absence of female sexual characteristics, webbed neck and cubitus valgus; previously, Otto Ullrich had also described the same clinical picture in $1930 .{ }^{[2]}$ In 1959 Ford et al. reported the loss of one of the X chromosomes in patients with Turner syndrome. ${ }^{[3]}$

About $1 \%$ to $2 \%$ of all conceptions have an X monosomy; $99 \%$ of them end in spontaneous abortions, usually during the first trimester of pregnancy; then the disorder affects only
1 in 1,800-5,000 live births in different populations. The reported prevalence in the world is $1: 2,000$ to $1: 5,000$ live newborn females. ${ }^{[4]}$

The most common cytogenetic presentation form of Turner syndrome is $45, \mathrm{X}$; however, about $50 \%$ of patients have a different chromosome formula. The $45, \mathrm{X} / 46, \mathrm{XY}$ variety is rare and reported in about $5 \%$ of cases. ${ }^{[5]}$

$45 \mathrm{X} / 46 \mathrm{XY}$ mosaicism is an extremely rare disorder, its incidence in the general population varies between 1.5/10,000 and 1.7/10,000 depending on the series. ${ }^{[6]}$ It is considered that detection of material corresponding to $\mathrm{Y}$ chromosome is growing due to more frequent use of techniques such as FISH, which could mean that true incidence of this phenomenon among patients with Turner syndrome may range from $10 \%$ to $15 \%{ }^{[6]}$

\footnotetext{
*Correspondence: Godfrey Mutashambara Rwegerera; Email: grwege@ yahoo.com; Address: Private Bag 00713, Faculty of Medicine, Univeristy of Botswana, Botswana.
} 
The clinical phenotype of patients with $45, \mathrm{X} / 46$, XY mosaicism is broad, ranging from women, with or without Turner syndrome stigmata, to apparently normal males, with intervening variable ambiguous phenotypes. ${ }^{[4]}$ Gonadal histology associated with $45, \mathrm{X} / 46, \mathrm{XY}$ mosaicism is also variable with partial, complete, mixed or asymmetric gonadal dysgenesis. ${ }^{[7,8]}$

In this article we describe a case of a female patient with normal external and Turner syndrome stigmata whose chromosome formula was $45, \mathrm{X} / 46, \mathrm{XY}$, one of the less frequent cytogenetic varieties of this syndrome.

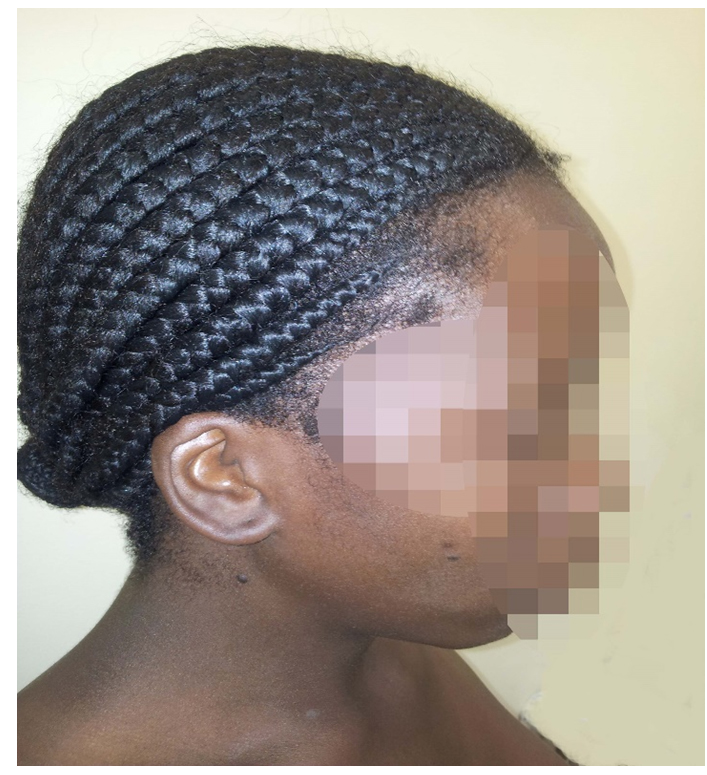

Figure 1. Short and wide neck without pterigeon colli, low-set ears, multiples nevi and low hair line at the back of the neck are evident

\section{Case presentation}

A 32-year-old black African female patient from a rural area of Botswana was referred to the Endocrinology Clinic because of primary amenorrhea. She had started oral contraceptive pills five years ago prescribed by a General Practitioner to induce menses. The menstrual periods were regular whenever she was taking pills, disappearing each time she stopped the medication. She had attended normal school and reported to be performing well throughout and attained a secretarial certificate and worked as a secretary in a public office with no reported complaints about her performance. There was no family history of primary amenorrhea or short stature, the mother height was $1.62 \mathrm{~m}$ and her menarche began when she was 12 years old; the father was not evaluated but his height was reported to be higher than the mother. Patient's findings on physical examination were as follows: Height: $1.48 \mathrm{~m}$, Weight: $52 \mathrm{~kg}$, BMI: $23.7 \mathrm{~kg} / \mathrm{m}^{2}$, short and wide neck without pterigeon colli, low-set ears, ocular hypertelorism and epicanthal folds were noted (see Figure 1) and fish-like mouth. On the skin multiples nevi and low hair line at the back of the neck (see Figures 1,2). The chest was broad (shield chest) and hypertelorism (widely space nipples), cubitus valgus and genus valgus were also noted. In addition both breasts were well developed (Tarner V), pubic hair distribution Tarner IV and normal external female genitalia with $6 \mathrm{~cm}$ vagina size, clitoris was normal at $1 \mathrm{~cm}$ in size (see Figures 2, 3).

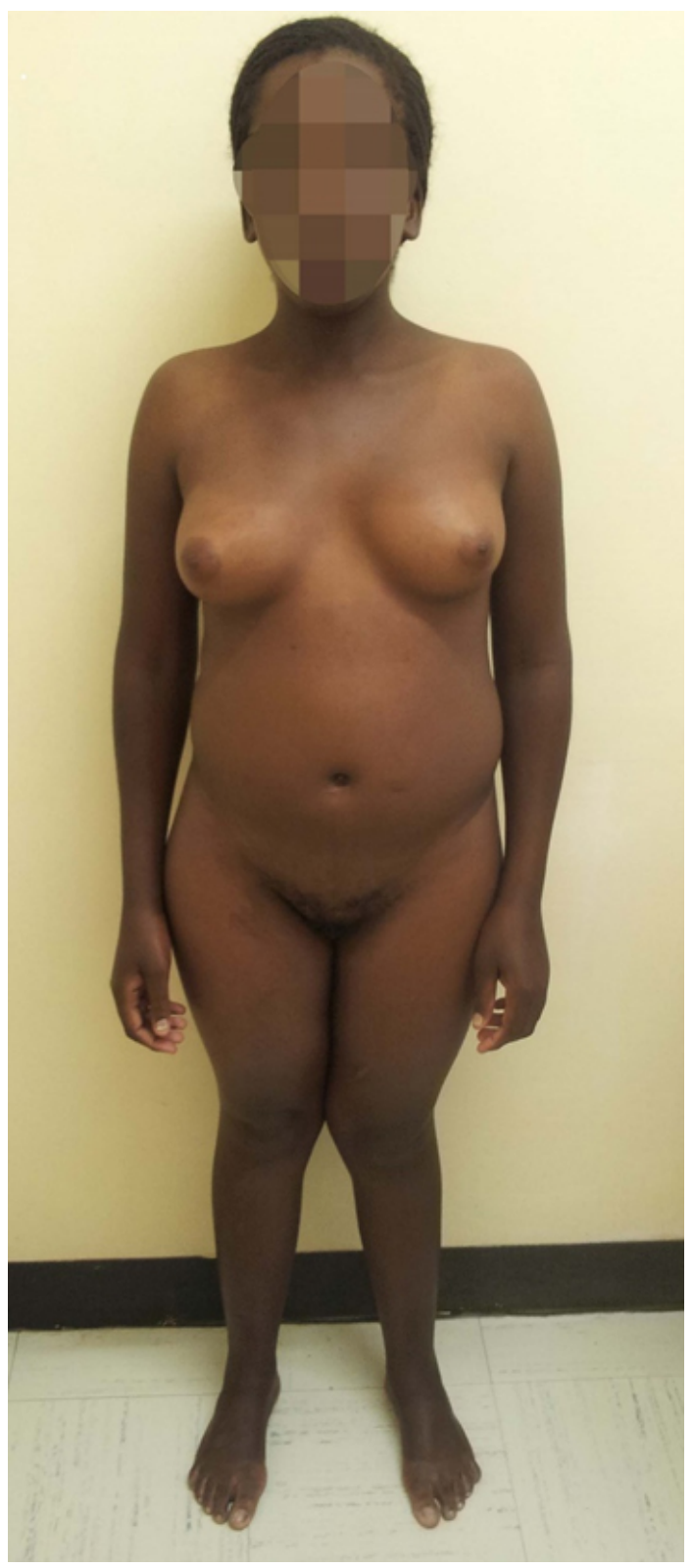

Figure 2. Broad chest (shield chest) and hypertelorism (widely space nipples), cubitus valgus and genus valgus are noted. Breast Tarner $\mathrm{V}$ development and pubic hair Tarner IV 


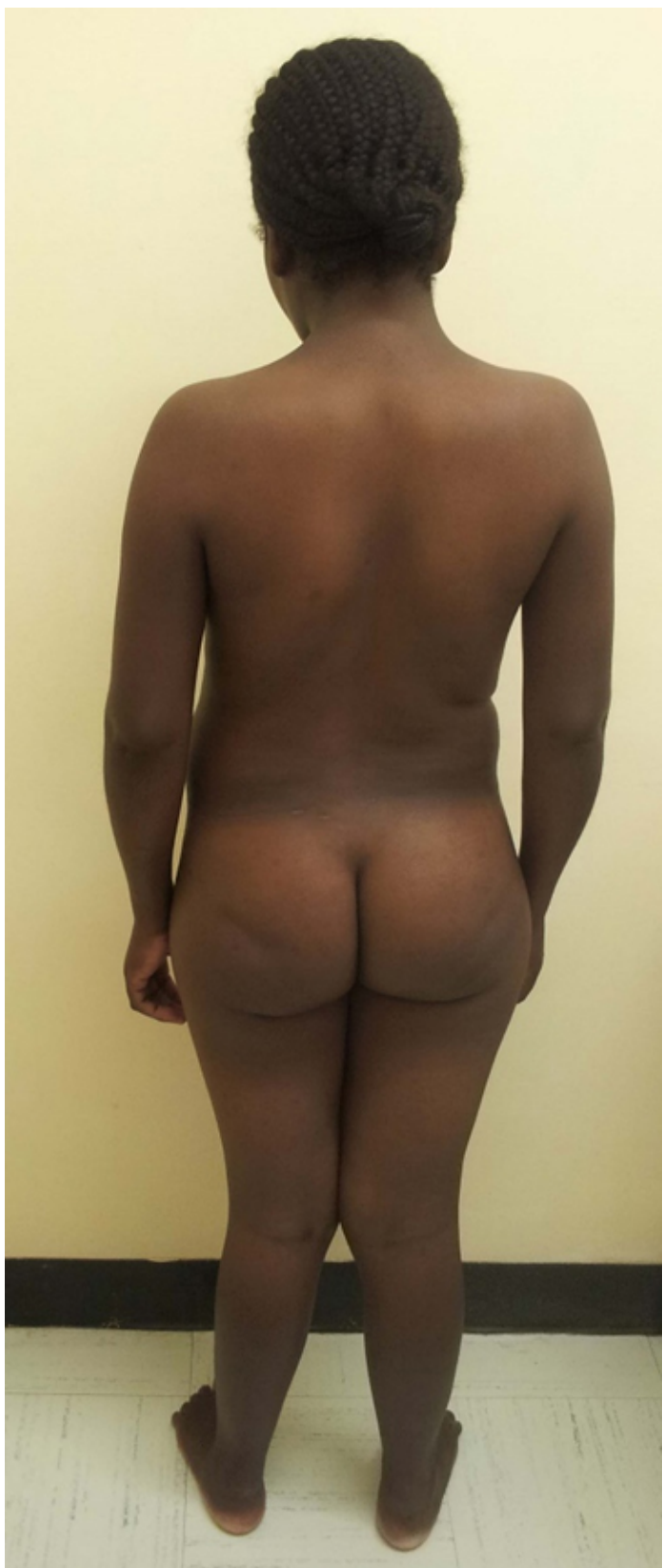

Figure 3. Broad chest (shield chest) and genus valgus are noted short and wide neck without pterigeon colli

Hormonal assays were as follows: Estradiol: $14 \mathrm{pmol} / \mathrm{L}$ (57-227), FSH: $82.7 \mathrm{mIU} / \mathrm{ml}$ (2.5-10.2), LH: $57 \mathrm{mIU} / \mathrm{ml}$ (1.9-12.5), Free Testosterone: $0.75 \mathrm{nmol} / \mathrm{L}(0.5-2.6)$, IGF 1: 198 ng/ml (107- 246), TSH: 1.7 mUI/L (0.35-6.5), FT4: 13.5 pmol/L (11.5-22.5), FT3: 3.9 pmol/L (3.5-6.5).

Cytogenetic analysis of cultured peripheral blood metaphase revealed a mosaic pattern with 2 cells lines being present: 17 of 30 cells analyzed (57\%) had a modal number of $46 \mathrm{Y}$ and 46X karyotype consistent with a male chromosome pattern, and 13 of 30 cells analyzed (43\%) had a modal number of 45 and a 45X karyotype consistent with a Turner Syndrome.
The findings were consistent with a diagnosis of $45, \mathrm{X} / 46$, XY mosaicism.

Echocardiogram and renal ultrasound studies to assess cardiac, aortic, and kidney structure were negative for anomalies associated with the $45, \mathrm{X}$ karyotype.

Laparoscopy revealed bilateral fallopian tubes, streak gonads, and hypoplastic uterus. Unfortunately, the patient had been reviewed by Gynecologist before chromosomal analysis result, when reviewed with results by Gynecologist the patient did not consent to the procedure despite the increased risk of malignancy in TS with streak gonads being thoroughly narrated to her.

After the diagnosis was confirmed a cyclic hormonal replacement was given;- it contained conjugated Estrogen 0.625 $\mathrm{mg}$ daily and cyclic Medroxyprogesterone acetate $10 \mathrm{mg}$ for 10 days each month resulting in regular menstrual cycle on subsequent follow up visits.

\section{Discussion}

In the literature review, different authors around the world have reported similar cases with karyotype 45, X/46, XY and female phenotype with Turner syndrome stigmata, ${ }^{[4,6,9,10]}$ however few cases are reported for Africa. ${ }^{[11-13]}$ This is the first case of Turner syndrome to be reported in Botswana. Occurrence of two or more chromosomal lineages in the same person defines mosaicism. For patients with 45, X/46, $\mathrm{XY}$ mosaicism, the different proportions of the 45, $\mathrm{X}$ and 46 , $\mathrm{XY}$ chromosomal cell lines among the tissues in individuals with this mosaicism presumably reflect the wide variety of phenotypes observed. ${ }^{[9,14]}$

Turner syndrome mosaicism phenotypes range from apparently normal male development to individuals with incomplete sexual differentiation and clinical signs of TS in both males and females. The most common presentation is sexual ambiguity, accounting for approximately $60 \%$ of cases, less common categories of $45, \mathrm{X} / 46, \mathrm{XY}$ patients present with bilaterally descended testes in about $11 \%-12 \%$ and normal female phenotype with Turner syndrome stigmata in less than $5 \%$ of all of cases. ${ }^{[10,14]}$ Our patient had a normal female phenotype corresponding to the less common of presentations described.

In cases without sexual ambiguity, first diagnosis is commonly made at puberty. ${ }^{[14]}$ Investigations in these cases tend to start in the puberty period triggered by the absence of menarche and lack of development of secondary sexual characteristics. Similarly, the diagnosis was delayed in our patient; the patient first attended consultations when she was already in adulthood. The patient was latter referred to 
specialized Endocrinology Clinic where the diagnosis was made, this shows that; TS and its variants may go unnoticed by gynecologists and general practitioners who were the first professionals to see this patient. The time of diagnosis has a direct impact on management and ultimately determines final stature.

Our patient was carrying clinical features of stigmata of TS and congenital anomalies associated with this syndrome like skeletal anomalies, primary amenorrhea and dysmorphic features without signs of virilization. The laboratory parameters were consistent with the characteristic hypergonadotropic hypogonadism found in the TS, with normal testosterone level and low oestradiol attributed to primary ovarian failure in these patients. Similar hormonal pattern were reported by different authors in their case series. ${ }^{[6,9,11]}$

Delayed sexual development and sexual infantilism are constant features in TS, ${ }^{[15]}$ our patient was taking contraceptive pills for 5 years so a normal genital development was seen in the moment of the assessment.

Short stature is also an invariant feature in $45, \mathrm{X}$ individuals and its variants and is characterizes by a tendency of intrauterine growth retardation as well as growth failure during childhood and reduced adult height. ${ }^{[16,17]}$ Short stature is not attributable to a deficiency of growth hormone, insulin-like growth factor I (IGF-I), adrenal or gonadal steroids. Decreased amplitude and frequency of growth hormone pulses have been reported after 8 years of age. Likewise, IGF-I levels that are normal up to 10 years of age are low thereafter; however, administration of either estrogen or growth hormone induces a rise in the concentration of plasma IGFI. The changes in growth hormone secretory dynamics and IGF-I concentrations after 8 to 10 years of age are probably secondary to the lack of the estrogen-induced rise in plasma growth hormone concentration and IGF-I levels at puberty. The cause of the progressive growth failure is attributable in these cases, at least in part, to the missing PAR1 gene, PHOG or SHOX, on the absent or structurally abnormal second sex chromosome. ${ }^{[18,19]}$ The mentioned genetic studies are not available in our facility, hence they were not performed.

The strongest expression of SHOX gene in patients can also explain the skeletal defects (cubitus valgus, genus valgus), seen in turner syndrome patients. ${ }^{[19]}$

Some dysmorphic features such as low implantation of hair, short and wide neck, low-set ears, epicanthal folds, fish-like mouth, multiple nevi and hypertelorism which are observed in individuals with Turner syndrome have also been observed among patients with $45, \mathrm{X} / 46, \mathrm{XY}$ mosaicism. The presence of these findings suggests an expression of a somatic $45, X$ cell line. ${ }^{[20]}$

Administration of pharmacologic doses of biosynthetic growth hormone increases growth rate and augments final height by a mean of $5 \mathrm{~cm}$ to $10 \mathrm{~cm}$, it is recommended to start as soon as the height falls below fifth percentile for age which usually occurs between 2 and 3 years of age ${ }^{[18,21]} \mathrm{Re}$ cent studies have demonstrated a gain of $8 \mathrm{~cm}-12 \mathrm{~cm}$ in girls with Turner's syndrome treated with Growth hormone $(\mathrm{GH})$ or with a combination of GH and Oxandrolone. ${ }^{[22]}$ Unfortunately our patient came too late to the Endocrine clinic when the final height was already attained and no benefit would be achieved by GH therapy, hence it was not prescribed in our patient.

The phenotype of female external genitalia in patients with $45, \mathrm{X} / 46, \mathrm{XY}$ mosaicism is usually associated with bilateral streak gonads but gonadoblastoma can be evident even at an early age in streak gonads with Y mosaicism and may be bilateral. Due to the high risk of malignant transformation for streak gonads, laparoscopic gonadectomy should always be performed, especially as it does not affect fertility and carries less surgical morbidity. ${ }^{[23]}$ Previously, the risk of gonadal malignancy in individuals with $45, \mathrm{X} / 46, \mathrm{XY}$ mosaicism has been described to be $10 \%-15 \%$ however the incidence in the literature varies from 10 to $30 \% .{ }^{[24]}$ Silveri et al. recently reported that of the 6 patients with TS mosaicism that underwent prophylactic laparoscopy $100 \%$ were diagnosed to have gonadoblastoma. ${ }^{[25]}$

Gonadoblastoma occur almost exclusively in patients with dysgenetic gonads and can be classified as an in situ cancer, the prognosis is uniformly good when they are completely removed and do not contain any elements of the more aggressive germ cell tumors. However, dysgerminomas and other even more malignant germ cell tumors may occur within or associated with gonadoblastoma. ${ }^{[26]}$ Unfortunately the patient rejected the surgery even when the risk was properly explained.

This patient has an uncommon chromosomal formula of Turner syndrome without signs of virilization, whereas it is true that the clinical findings directed to the diagnosis of TS, the study of karyotype was decisive for classification.

Hormonal therapy replacement is indicated in order to induce and maintain secondary sexual characteristics and cyclic menses, to optimize bone mineral density, to keep cognitive and motor function and to prevent cardiovascular diseases. ${ }^{[18,27]}$

In conclusion, Turner Syndrome has different cytogenetic and chromosomal subtypes including Y chromosome mosaicism. The chromosome study is crucial for proper diag- 
nostic classification. The management of these cases should be integrated and individualized, assessing different aspects like sexual development, growth development and the presence of other associated comorbidities. The presence of $\mathrm{Y}$ chromosome predisposes to development of dysgenetic tumors; hence removal of the streak gonads should be ad- vised. Proper hormonal therapy like growth hormone and sex steroids should be initiated early as it determines the patients' future quality of life.

\section{CONFlicts OF InTEREST Disclosure}

The authors have declared no conflicts of interest.

\section{REFERENCES}

[1] Pérez Bueno F, Aguilera Pérez JR, Garza Ríos P. Reemplazo estrogénico en pacientes con síndrome de Turner. Perinatologia y Reproduccion Humana. 2015; 29(3): 122-129. http://dx. doi .org /10.1016/j.rprh.2015.08.002

[2] Turner HH. A syndrome of infantilism, congenital webbed neck, and cubitus valgus. Endocrinology. 1938; 23: 566-574. PMid:4557013 http://dx.doi.org/10.1210/endo-23-5-566

[3] Ford CE, Jones KW, Polani PE, et al. A sex chromosome anomaly in a case of gonadal dysgenesis (Turner's syndrome). Lancet. 1959; 1(7075): 711-13. PMid:13642858 http://dx.doi.org/10.1016 /S0140-6736 (59) 91893-8

[4] Saldarriaga WG, Sánchez FA, de Lourido I. Síndrome de turner con mosaicismo 45x/46xy: reporte de caso. Rev Chil Obstet Ginecol. 2011; 76(1): 47-51. http://dx.doi.org/10.4067/S0717-752 62011000100010

[5] Firth H, Hurst J. Turner syndrome 45X and variants. Oxford Desk reference. Clinical genetics. 1 th edition. New York. Oxford University Press. 2007; Cap 5: 558-60.

[6] El Moussaif N, El Haddad N, Iraqi N, et al. 45X/46XY mosaicisme: report of 5 cases and clinical review. Annales d' Endocrinologie. 2011; 72: 239-243. PMid:21640978 http://dx.doi.org/10.10 $16 / \mathrm{j}$. ando. 2011.04 .009

[7] Ocal G, Berberoglu M, Siklar Z, et al. The clinical and genetic heterogeneity of mixed gonadal dysgenesis: does "disorders of sexual development (DSD)" classification based on new Chicago consensus cover all sex chromosome DSD? European Journal of Pediatrics. 2012; 171(10): 1497-1502. PMid:22644991 http://dx.doi.org /10.1007/s00431-012-1754-0

[8] Soares H, Maia A, Campos M, et al. Clinicopathological features of 45, X/46, Xidic (Y) mosaicism and therapeutic implications: case report. Sao Paulo Med J. 2008; 126: 297-299. PMid:19099167 http://dx.doi.org/10.1590/S1516-31802008000500012

[9] Rosa RF, D'Ecclesiis WF, Dibbi RP, et al. 45, X/46, XY mosaicism: report on 14 patients from a Brazilian hospital. A retrospective study. Sao Paulo Med J. 2014; 132(6): 328-34. PMid:25351753 http://dx.doi.org/10.1590/1516-3180.2014.1326729

[10] Tokmak A, Akselim B, Yesilyurt H. Turner Syndrome with 45, X/46, $\mathrm{XY}$ mosaicism underwent gonadectomy: Report of 3 cases. Eastern Journal of Medicine. 2015; 20(2): 117-119.

[11] Elleuch M, Mnif Feki M, Kammoun M, et al. Descriptive analyses of Turner syndrome: 49 cases in Tunisia. Ann Endocrinol (Paris). 2010; 71(2): 111-116. PMid:20153455 http://dx.doi.org/10. $1016 / j$. ando.2009.12.013

[12] Wonkam A, Veigne SW, Abass A, et al. Features of Turner syndrome among a group of Cameroonian patients. Int J Gynaecol Obstet. 2015; 129(3): 264-266. PMid:25912411 http://dx.doi.org/10.1016 /j.ijgo.2014.11.025
[13] Mensah-Ado I, Lauhbouet MD, Lokrou A, et al. Turner syndrome: mosaic and isochromosome $\mathrm{q}$ in a young African woman. Med Trop (Mars). 1994; 54(4): 349-351. PMid:7746129

[14] Tosson H, Rose SR, Gartner LA. Description of children with 45, X/46, XY karyotype. Eur J Pediatr. 2012; 171(3): 521-9. PMid:21997800 http://dx.doi.org/10.1007/s00431-011-1 600-9

[15] Sparkes RS, Motulsky AG. The Turner Syndrome with Isochromosome X and Hashimoto's Thyroiditis. Ann Intern Med. 1967; 67(1): 132-144. PMid:6071743 http://dx. doi .org/10.7326/0003-4 819-67-1-132

[16] Martinerie L, Morel Y, Gay CL, et al. Impaired puberty, fertility, and final stature in 45, X/46, XY mixed gonadal dysgenetic patients raised as boys. Eur J Endocrinol. 2012; 166(4): 687-94. PMid:22236473 http://dx.doi.org/10.1530/EJE-11-0756

[17] Telvi L, Lebbar A, Del Pino O, et al. 45, X/ 46, XY mosaicism: report of 27 cases. Pediatrics. 1999; 104(2 Pat 1): 304-308.

[18] Melmed SH, Polonski K, Reed P, et al. Williams textbook of Endocrinology (13th ed). Philadelphia PA. Pediatric disorders of sex development. 2016: 896-912.

[19] Clement-Jones M, Schiller S, Ercole R, et al. The short stature homeobox gene SHOX is involved in skeletal abnormalities in Turner Syndrome. Human Molecular Genetics. 2000; 9(5): 695-702. PMid:10749976 http://dx.doi.org/10.1093/hmg/9.5.695

[20] Méndez JP, Ulloa-Aguirre A, Kofman-Alfaro S, et al. Mixed gonadal dysgenesis: clinical, cytogenetic, endocrinological, and histopathological findings in 16 patients. Am J Med Genet. 1993; 46(3): 263 267. PMid:8488868 http://dx.doi.org/10.1002/ajmg. 1320 460304

[21] Lanes R. Growth velocity, final height and bone mineral metabolism of short children treated long term with growth hormone. Curr Pharm Biotechnol. 2000; 1(1): 33-46. PMid:11467359 http: //dx.doi .o rg/10.2174/1389201003378997

[22] Rosenfeld RG, Frane J, Attie KM, et al. Six year results of a randomized, prospective trial of human growth hormone and oxandrolone in Turner syndrome. J Pediatr. 1992; 121: 49-55. http: //dx.doi.org/10.1016/S0022-3476(05)82540-5

[23] Brant WO, Rajimwale A, Lovell MA, et al. Gonadoblastoma and Turner syndrome. J Urol. 2006; 175(23): 1858-1860. http://dx.d oi .org/10.1016/S0022-5347(05)00932-8

[24] Johansen M, Hagen C, Rajpert-De Meyts E, et al. 45, X/46, XY Mosaicism: Phenotypic Characteristics, Growth, and Reproductive Function-A Retrospective Longitudinal Study. J Clin Endocrinol Metab. 2012; 97(8): E1540-E1549. PMid:22605431 http://dx.d oi.org/10.1210/jc.2012-1388

[25] Silveri M, Grossi A, Bassani F, et al. Ullrich-Turner Syndrome and Tumor Risk: Is There Another Chance to Early Gonadectomy in Positive TSPY and SRY Patients? Eur J Pediatr Surg. 2016; 26(03): 273-276. PMid:25978024 
[26] McDonough PG, Tho SP. Clinical implications of overt and cryptic $\mathrm{Y}$ mosaicism in individuals with dysgenetic gonads. International Congress Series. 2006; 1298: 13-20. http://dx.doi.org/10.10 $16 / j$.ics.2006.06.011
[27] Cintron D, Rodriguez-Gutierrez R, Serrano V, et al. Effect of estrogen replacement therapy on bone and cardiovascular outcomes in women with turner syndrome: a systematic review and meta-analysis. Endocrine. 2016. PMid:27473099 http://dx.doi.org/10.1007 /s12020-016-1046-y 